\title{
First Elements about the Problems of the Cohabitation of Generations within Companies in Lebanon
}

\author{
Inaya Wahidi ${ }^{1} \&$ Robert Paturel $^{2}$ \\ ${ }^{1}$ Faculty of Economics and Business Administration, Lebanese University, Hadath, Lebanon \\ ${ }^{2}$ IAE of Brest, University of Bretagne Occidentale, Brest, France \\ Correspondence: Inaya Wahidi, Faculty of Economics and Business Administration, Lebanese University, \\ Hadath, Lebanon. E-mail: inaya_wahidi@hotmail.fr or inaya.wahidi@ul.edu.lb
}

Received: January 11, 2017

doi:10.5539/ijbm.v12n3p241
Accepted: February 17, 2017 Online Published: February 22, 2017

URL: https://doi.org/10.5539/ijbm.v12n3p241

\begin{abstract}
In Lebanon, the global unemployment rate affects $25 \%$ of the working population (figures from the Ministry of Labor 2014 cited by Ghosn, 2015). Young people aged from 20 to 29 are rather excluded from work in the country with an unemployment rate of $42 \%$ in 2012 (Ghosn, 2015). The youth unemployment rate was $32.8 \%$ (20-24 years) and 21.6\% (25-29 years) according to the latest known statistics in Lebanon (CAS Report 2009, p.22). In 2016, the unemployment rate among young Lebanese is the highest among the Arab countries with $30 \%$ of unemployed (Belga, 2016). The nature of intergenerational relations in Lebanese companies is slightly studied till now. Our work will highlight the main factors explaining the oppositions or exchanges between young and older in companies in Lebanon. We conduct a quantitative study using questionnaire administered to the CEOs of engineering and food industry firms. Our two samples consist of 147 engineering firms and 150 food industry firms. Concerning intergenerational oppositions, the results show that older employees criticize young people for their weak attachment to the company and to the work in the sector of engineering. For their part, young people holders of higher diplomas than seniors accuse them of incompetence at work and vice versa in the food industry. Concerning intergenerational exchanges, older people are helping young people experiencing difficulties in the workplace and the existence of shared moments between older and young people has been noted as positive in the food industry sector.
\end{abstract}

Keywords: generations at work, intergenerational cooperation at work, intergenerational opposition at work

\section{Introduction}

Cooperation between generations at work presents a challenge for companies facing a highly competitive environment. The maintenance of the relational balance between the young and older employees at work has a strong influence on the performance of a company, hence the importance of its regulation by managers. In a competitive environment where information flows rapidly, a quiet working environment is sought with a reduced conflict between staff members. Several researchers have addressed the topic of intergenerational cooperation or opposition at work in the literature, such as Delay (2008a, 2008b) and Rosanvallon (2013). The analysis of the manager role concerning the management of the generations at work in the cedar country does not exist to our knowledge, whereas the nature of this relationship seems to be important to promote the sustainability and the good functioning of the companies. The proportion of unemployed graduates and their emigration rates is very high in Lebanon (Longuenesse, 2011) and stress dominates the life of the people. According to ILO figures (cited by Ghosn, 2015), "33\% of graduates are unable to find a job" and " $40 \%$ of young Lebanese graduates leave Lebanon less than five years after graduation ( world bank figures cited by Ghosn, 2015). With a minimum wage of $\$ 450$ that does not cover the needs of the Lebanese, the social climate cannot be serene. It also seems that young workers are better educated than older workers (Delay, 2008) and overqualified for positions held in Lebanon (Ghosn 2015). The rate of young unemployed (20-29 years) is very high and represents $42 \%$ in 2012 (figures from the national youth policy paper in 2012 cited by Ghosn, 2015). Young people are rather excluded from work in the country. The unemployment rate for young people was $32.8 \%$ (20-24 years) and $21.6 \%$ (25-29 years) according to figures from the latest known statistics in Lebanon and provided by the Central Administration of Statistics for 2009 (CAS Report, 2009, p.22). In 2016, unemployment among young Lebanese is the highest among the Arab countries, with $30 \%$ of unemployed (ILO figures in 2016, cited by Belga, 2016). 
However, work must not exclude anyone (Delay, 2008). So, generational equilibrium may do not exist at work and the study of the nature of intergenerational relations in Lebanese companies is important to deepen, although the figures relating to the percentages of young and older at work are absent in Lebanon. Our work will highlight the main factors explaining the oppositions or exchanges between young and older in companies in Lebanon. Our research question is as follows: What are the main factors explaining the oppositions or exchanges between young and older in companies in Lebanon? To answer this question, we will first present a brief review of the literature and the objectives of the investigation. We will present our research methodology in a second step. The results and their analysis will be developed in a third stage. We will discuss the results while stressing the limitations of our work in a fourth time, before concluding.

\section{Brief Literature Review and the Objectives of the Research}

In this section, we will discuss the importance of studying the generations at work in the literature. Generations of employees working in firms have been approached by several researchers such as Pialoux, Weber and Beaud (1991), Dubar (2000), Wagner (2004), Moatty (2004), Chauvel (1998) and Hughes ( cited by Rosanvallon, 2013). But before going any further, it seems important to define what is meant by generations at work. Delay (2008a, 2008b) distinguished two categories: the under-30s (young) and the over-50s (the oldest). Meda and Vendramin (2010) proposed three categories: Those under the age of 30 (the young), those aged from 30 to 50 (the older) and those over 50 (the oldest). Researchers have addressed the role of work by young people and others (Meda and Vendramin, 2010, Rahmil, 2016). Meda and Vendramin (2010) argue that young Europeans do not differentiate themselves from the oldest with regard to the place assigned to work. They find that conflict does not exist although inequalities exist between them. Similarly, Rahmil (2016) argues that the literature highlights the high use of technology by young people as a factor of confrontation with older workers at work, but that young people show a desire for greater cooperation with their elders. Other studies have emphasized the importance of working for young people without making a comparison with other members of the firm (Krahn and Galambos, 2014; Abrudan et al., 2016).

The analysis has focused on factors that lead to opposition or exchange between generations at work (Delay, 2008a, 2008b; Rosanvallon, 2013). Delay (2008a, 2008b) conducted two studies that examined the factors of conflict or cooperation between youth and elders at work. It identified several factors at the origin of the opposition between generations as the level of the diploma, higher among young people compared to the rest of the salaried population, and the incompetence of the older perceived by young people (Delay, 2008a). She finds that when the co-apprenticeship is promoted young/older and globally the formation of the young by the elders, the opposition between the generations is reduced more and more. According to the results of the study done by (Delay, 2008b), attachment to the work is as strong for young as for the older. Taking the example of EDF (Electricity of France), Rosanvallon (2013) noted that generations are less opposed even if there is a cultural divergence. According to the author, generations come into conflict because: (1) elders blame young people for their weak attachment to the work and for the lack of training; (2) they find that their salaries are equivalent to those of young people, or even lower; (3) older people do not help young people facing difficulties at work; (4) the two generations do not enjoy moments of conviviality together. The author concludes that they are less opposed when their interactions are occasional. He adds that they take an identical interest in the development of the company and that the cooperation between them exists despite the presence of a cultural difference. Studies have focused on managerial responsibility in conflicts or intergenerational co-operation at work (Delay, 2008a, 2008b). It seems important to clarify that the exchange between young and older employees "is not limited to instructions but to a real non-programmed interaction "(Delay, 2008a). But before thinking of studying the role of the manager in intergenerational relationships at work, it is necessary to understand the nature of these relationships in companies in Lebanon that constitute our field of research. This work will highlight the main factors explaining the oppositions or exchanges between young and older in companies in Lebanon, which will provide initial information on this topic and a brief characterization of intergenerational relations between Lebanese employees.

\section{Methodology}

We now present the nature of the research (3.1), the sample and data collection method (3.2), the operationalization of the variables (3.3) and the choice of the data processing techniques (3.4).

\subsection{The Nature of the Research}

We can characterize our investigation according to the following characteristics (Paturel, 2004). Our academic work is a clinical research based on strong or slight depth interviews (variable duration).It is rather informative and instantaneous that it is an exploitation of data collected at a given time in a particular and dated context from 
Lebanon. The analysis of the information obtained can be considered as quantitative, with the intention to measure this phenomenon. The investigation involved a wide sample compared to the original population and the processing of the data was carried out by simple but explanatory statistical methods. The research remains exploratory and limited on a subject sparsely or not treated on the ground retained and it is a kind of a debate research to be extent because there are many points in the shadow that need to be clarified by other work in the years to come.

The study aims to present information (obtained from the CEOs) on the intergenerational relations of workers in companies in Lebanon.

\subsection{Sample and Data Collection}

Our research started in October 2016 by contacting the companies by telephone to administer a questionnaire to the CEO on the issue of intergenerational relationships at work, neglected topic in Lebanon till now. It seems important to say that their age varies from 38 to 62 years. Our study is focused on two samples. The first belongs to civil engineering, architecture, construction studies, geotechnical/mechanical engineering and topographical studies, and the second to the food industry consisting of packaging, packaging and the preservation of all types of meat, the production of chips, soft drinks, oils, margarines, dairy products, bread, ice cream, confectionery, biscuits, chocolates, chewing gums, dry fruits, pasta, roasting coffee and the packaging of tea and herbal teas, the vinegar industry, sauces, yeast, alcohol, wine, beer, water and juices. We chose these two sectors of activity because we had access to the lists of member companies in the Chamber of Commerce, Industry, and Agriculture of Beirut. These lists concern companies in Beirut and Mount Lebanon only. According to these statistics, there are 156 member companies of engineering and 1682 industrial enterprises of which 458 intervening in the food industries. Our first sample consists of 147 engineering firms. We contacted the 156 companies and we had a return of 147 of them, a response rate of $94.23 \%$. Our second sample includes 150 industrial food companies. We contacted 248 companies because the remaining 210 did not accept the administration of the questionnaire. For some, their telephone line was no longer in service; we had 150 responses, a return rate of $60.48 \%(150 / 248)$. For the remaining companies (98/248), we have not been able to contact the CEO despite several phone calls, either because it was not in the office, or he was traveling or in a meeting. In both cases, we can consider that the response rates are excellent, with almost the entire initial population in the engineering sector and almost a third of the population targeted for the food industry. Let us add that the two samples have an almost identical number (147 and 150 members).

Finally, our work was spread out from October 2016 to January 2017 and the duration of the interviews varied from 15 to 20 minutes per CEO interviewed.

Concerning our questionnaire, we began by explaining the two terms young and older in age groups with $<30$ years for young people and 30 to 50 years and $>50$ years for others. Then, we asked for general information such as the average age of the majority of the employees ( $<30$ years, 30-50 years, $>50$ years) and the gender of the majority of the employees in the company. We also asked a question related to the state of intergenerational relationships of employees at work to highlight the perception of CEOs on the issue. Finally, we asked two main questions, each of which is specific to a group of nine questions. The first question focuses on the determinants of the opposition or conflict between young ( $<30$ years) and older (30-50 and $>50$ years) at work. The second concerns cooperation or exchanges between them.

\subsection{Operationalization of Variables}

Before describing our variables, we must define the age categories that interest us. Inspired by Meda and Vendramin (2010), we decided to retain three age categories divided into two groups with young ( $<30$ years) and older (30-50 and $>50$ years).Inspired by Delay (2008a), we elaborated our dependent variable "genrelat" which synthesizes the intergenerational relationship at work. We used the following Likert scale to answer this question: Does the state of the relations between older and young workers in your company is good? 1- strongly agree; 2agree; 3- neither agree nor disagree; 4- disagree; 5-strongly disagree. Inspired by the writings of Delay (2008a) and Rosanvallon (2013), we have determined the independent variables. We have nine independent variables related to opposition or conflict between young and older and nine other variables related to cooperation or exchanges between them. We have planned a specific question to each group of independent variables: "The older and young employees of your company are more opposed because ..." and "The older and young employees of your company cooperate more because ...". We have used the following Likert scale at five levels with 1- Strongly disagree; 2- disagree; 3 - neither agree nor disagree; 4- agree; 5-strongly agree.

Concerning the opposition or the conflicts between the young and the older at work, the independent variables are the following ones: 
- Older blame young for their weak attachment to the business and to the work;

- Elders highlight the lack of training among young;

- The older find that the salaries of young are equivalent to their own salaries, even higher;

- The older find that young decide to go to another company when a crisis occurs;

- Elders do not help young facing difficulties at work;

- There is a lack of collective moments of conviviality between the older employees and the young of the company;

- Young are holders of diplomas that are superior to those of the older;

- Some older workers accuse young people of incompetence at work;

- Young workers accuse the older of incompetence at work.

Concerning the cooperation or exchanges between young people and older people at work, the variables are as follows:

- The interaction between the older and the young is occasional;

- The older and young workers cooperate even if there is a cultural divergence;

- The elder and young workers behave in the same way towards the customer;

- The older and young workers have an equal interest regarding the evolution of the company;

- Elders assist young workers facing work difficulties;

- There are collective moments of conviviality between the older employees and the young of the company;

- Young workers tolerate the low professional investment of some older workers arriving close to the retirement age;

- Intergenerational relations are improving when the older provide training for young;

- The co-learning seniors/young promote relationships between generations at work.

\subsection{The choice of the Data Processing Techniques}

We used the software SPSS 17 to obtain the frequency tables (descriptive statistics) and to use the PCA technique (principal components analysis) with a "varimax" rotation to minimize the number of variables having a strong correlation with each factor. The PCA allows the prioritization of factors, reducing the amount of information by grouping the various items measured to a small number of factors. This technique enables the testing of the validity of the scales via the KMO (Kaiser-Meyer-Olkin) test, which must be greater than 0.5 to allow the PCA execution reflecting the inter-correlation of the variables. The KMO is always accompanied by the Bartlett test which must be less than 0.5 for the variables to be correlated. Then, the Cronbach Alpha test was performed. It indicates the reliability and, therefore, the homogeneity of the scale. The minimum threshold of significance of the recommended Cronbach Alpha is 0.60 (Evrard et al., 1997, Igalens and Roussel, 1998, cited in Saleh 2011, p.295). According to the authors, it is suggested to eliminate items with a contribution less than or equal to 0.50 on the same factors. When the KMO, Bartlett and Cronbach Alpha tests were significant, we conducted multiple regressions to test the relationship between the dependent variable "VD: genderlat" and the independent variables already cited. Concerning multiple regressions, the Anova test preceding the regression test must be significant $(\mathrm{sig}<0.05$ ) in order to continue the reading of the results of the regression whose significance threshold must be less than 0.05 .These tests, which allow the execution of the multiple regression, leading to the determination of the intensity of the relationship between the independent variables specific to opposition factors or conflicts between young and older at work, and the state of intergenerational relationships of employees according to CEOs (dependent variable). Similarly, for the independent variables specific to the factors of cooperation or exchanges between the young and the older at work and the state of the intergenerational relations of the employees according to the CEO (dependent variable). Let us not forget that the PCA makes it possible to reduce the number of items (independent variables) specific to each independent metavariable: 1-opposition or conflicts 2- cooperation or exchanges. 
Factors of opposition or conflict between young (<30 years) and older (30-50 and $>50$ years) at work

- Older blame young for their weak attachment to the business and to the work;

- Elders highlight the lack of training among young;

- The older find that the salaries of young are equivalent to their own salaries, even higher;

- The older find that young decide to go to another company when a crisis occurs;

- Elders do not help young facing difficulties at work;

- There is a lack of collective moments of conviviality between the older employees and the young of the company;

- Young are holders of diplomas that are superior to those of the older;

- Some older workers accuse young people of incompetence at work;

- Young workers accuse the older of incompetence at work.

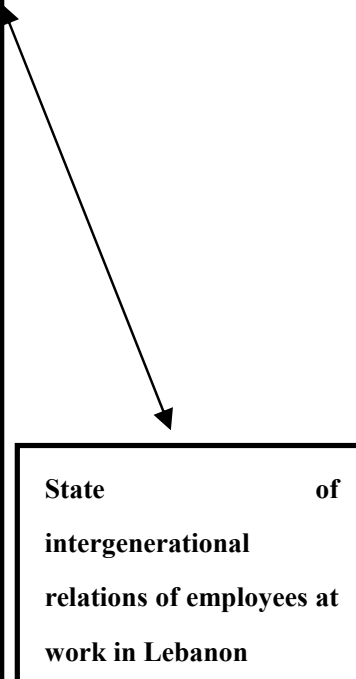

Factors of cooperation or exchange between young (<30 years) and older (30-50 years and $>50$ years) at work

- The interaction between the older and the young is occasional;

- The older and young workers cooperate even if there is a cultural divergence;

- The elder and young workers behave in the same way towards the customer;

- The older and young workers have an equal interest regarding the evolution of the company;

- Elders assist young workers facing work difficulties;

- There are collective moments of conviviality between the older employees and the young of the company;

- Young workers tolerate the low professional investment of some older workers arriving close to the retirement age;

- Intergenerational relations are improving when the older provide training for young;

- The co-learning seniors/young promote relationships between generations at work.

Figure 1. Towards a first modeling of the intergenerational relationship at work in Lebanon Source: Authors.

\section{Results and Analysis}

Table 1 below shows CEOs' responses to intergenerational relationships among employees at work. In the engineering sector, CEOs seem to strongly agree (76.9\% of responses), while in the food industry sector, CEOs strongly agree $(62.7 \%$ of respondent's answers) and agree (32.7\% of responses). In both sectors, we note the good perception of intergenerational relations at work by the CEOs because the answer "strongly disagree" represents only $0.7 \%$ and $4.6 \%$ respectively in the engineering sector and in the food industry.

Table 1. CEO's responses to the good state of intergenerational relations of employees at work

\begin{tabular}{|c|c|c|c|c|c|}
\hline $\begin{array}{l}\text { Sector / the good state of } \\
\text { intergenerational relations } \\
\text { of employees at work }\end{array}$ & Strongly agree & Agree & $\begin{array}{l}\text { Neither } \\
\text { agree } \\
\text { disagree }\end{array}$ & $\begin{array}{l}\text { Disagree } \\
\text { nor }\end{array}$ & Strongly disagree \\
\hline $\begin{array}{l}\text { Sector of engineering } \\
(N=147)\end{array}$ & $113(76.9 \%)$ & $23(15.6 \%)$ & $5(3.4 \%)$ & $5(3.4 \%)$ & $1(0.7 \%)$ \\
\hline $\begin{array}{l}\text { Sector of foodindustry } \\
(N=150)\end{array}$ & $94(62.7 \%)$ & $49(32.7 \%)$ & $0(0 \%)$ & $0(0 \%)$ & $7(4.6 \%)$ \\
\hline
\end{tabular}

Source: Authors. 
Table 2 below provides CEO responses on the age and gender of employees. In the engineering and food industries, it appears that the employees are older because their age is between 30 and 50 years, with $71.4 \%$ and $76 \%$, respectively. Moreover, employees are exclusively men in the engineering sector and almost exclusively male employees in the food industry (98\%).

Table 2. CEO's responses on age and gender of employees

\begin{tabular}{lllllll}
\hline $\begin{array}{l}\text { Sector / ageand gender } \\
\text { of employees }\end{array}$ & $\begin{array}{l}\text { Less than } \\
\text { years }\end{array}$ & $\begin{array}{l}\text { From } 30 \text { to } 50 \\
\text { years }\end{array}$ & $\begin{array}{l}\text { More than } \\
50 \text { years }\end{array}$ & Male & Female \\
\hline $\begin{array}{l}\text { Sector of engineering } \\
(N=147)\end{array}$ & $42(28.6 \%)$ & $\mathbf{1 0 5}(71.4 \%)$ & $0(0 \%)$ & $147(100 \%)$ & $0(0 \%)$ \\
$\begin{array}{l}\text { Sector of food industry } \\
(N=150)\end{array}$ & $36(24 \%)$ & $\mathbf{1 1 4}(76 \%)$ & $0(0 \%)$ & $\mathbf{1 4 7 ( 9 8 \% )}$ & $3(2 \%)$ \\
\hline
\end{tabular}

Source: Authors.

Table 3 below summarizes the results of the PCA, the Cronbach alpha and the multiple regression on the causes of opposition (or conflict) and exchange (or co-operation) between Young and older at work in the engineering sector in Lebanon. The results show the validity and reliability of the scale regarding the causes of intergenerational opposition. The results of the regression reveal a single cause of opposition: the older criticize young people for their weak attachment to the business and to the work. Concerning the reasons for intergenerational exchanges, the scale is invalid and therefore unreliable. Therefore, the regression test could not be conducted and the reasons for intergenerational exchanges in the engineering sector could not be detected.

Table 3. PCA, Cronbach Alpha and multiple regression on the causes of opposition (or conflict) and exchange (or co-operation) between young and older at work in the engineering sector in Lebanon (Varimax rotation)

\begin{tabular}{|c|c|c|c|c|c|c|}
\hline Meta-variables & $\begin{array}{l}\text { KMO (Validity test } \\
\text { of the scale) }\end{array}$ & $\begin{array}{l}\text { Bartlett } \\
\text { (Validity } \\
\text { test of the } \\
\text { scale) }\end{array}$ & $\begin{array}{l}\text { Cronbach } \alpha \\
\text { (Reliability } \\
\text { test of the } \\
\text { scale) }\end{array}$ & $\%$ of variance & Anova & $\begin{array}{l}\text { Multiple } \\
\text { regression }\end{array}$ \\
\hline $\begin{array}{l}\text { 1-The causes of } \\
\text { opposition (or } \\
\text { conflict) }\end{array}$ & $\begin{array}{l}0.578 \\
>0.5 \\
\text { The variables are } \\
\text { interrelated. }\end{array}$ & $\begin{array}{l}0.000<0.5 \\
\text { The } \\
\text { variables are } \\
\text { correlated }\end{array}$ & $\begin{array}{l}0.683> \\
0.60 \\
\text { This means } \\
\text { that } 68.3 \% \text { of } \\
\text { the scores are } \\
\text { true, so the } \\
\text { variables are } \\
\text { well } \\
\text { interrelated. }\end{array}$ & $\begin{array}{l}30.485 \\
20.504 \\
14.152 \\
\text { The first dimension } \\
\text { extracted explains } \\
30.485 \% \text { of the variance } \\
\text { of the phenomenon. The } \\
\text { most correlated factors ( } \\
0.50) \text { related to this } \\
\text { dimension are:(1) Older } \\
\text { blame young for their } \\
\text { weak attachment to the } \\
\text { business and to the work; } \\
\text { (2) they emphasize the } \\
\text { lack of training among } \\
\text { young; and (3) find that } \\
\text { young people leave their } \\
\text { jobs when a crisis occurs. }\end{array}$ & $\begin{array}{l}0.049<0.05 \\
\text { significant }\end{array}$ & $\begin{array}{l}\text { Older blame } \\
\text { young for their } \\
\text { weak attachment } \\
\text { to the business } \\
\text { and to the work: } \\
\text { Sig= } 0.013<0.05 \\
\text { significant }\end{array}$ \\
\hline
\end{tabular}




\begin{tabular}{|c|c|c|c|}
\hline $\begin{array}{l}\text { 2-The causes of } \\
\text { exchange (or } \\
\text { co-operation) }\end{array}$ & $\begin{array}{l}0.485 \\
<0.5 \\
\text { So, the variables are } \\
\text { not interrelated. } \\
\text { So the PCA cannot } \\
\text { be conducted. }\end{array}$ & 0.000 & $\begin{array}{l}0.065<0.60 \\
\text { This means } \\
\text { that } 6.5 \% \text { of } \\
\text { the scores are } \\
\text { true, so the } \\
\text { variables are } \\
\text { not } \\
\text { interrelated. }\end{array}$ \\
\hline
\end{tabular}

Source: Authors.

Table 4 presents the results of the PCA, the Cronbach alpha and the multiple regression on the causes of opposition and exchanges between young and older workers in the food industry at Lebanon. The results confirm the validity and the reliability of the scale relating to the causes of opposition and intergenerational exchanges. The regression data reveal three causes of conflict: (1) Young are holders of diplomas that are superior to those of the older; (2) Some older workers accuse young people of incompetence at work; (3) Young workers accuse the older of incompetence at work.

On the grounds of exchange or intergenerational collaborations, the regression results lead to two causes:(1) Elders assist young workers facing work difficulties; (2)There are collective moments of conviviality between the older employees and the young of the company;

Table 4. PCA, Cronbach Alpha and multiple regression on the causes of opposition (or conflict) and exchange (or co-operation) between young and older at work in the food industry sector in Lebanon (Varimax rotation)

\begin{tabular}{|c|c|c|c|c|c|c|}
\hline $\begin{array}{l}\text { Meta- } \\
\text { variables }\end{array}$ & $\begin{array}{l}\text { KMO } \\
\text { (Validity test } \\
\text { of the scale) }\end{array}$ & $\begin{array}{l}\text { Bartlett } \\
\text { (Validity test } \\
\text { of the scale) }\end{array}$ & $\begin{array}{l}\text { Cronbach } \alpha \\
\text { (Reliability } \\
\text { test of the } \\
\text { scale) }\end{array}$ & $\%$ of variance & Anova & $\begin{array}{l}\text { Multiple } \\
\text { regression }\end{array}$ \\
\hline \multirow{16}{*}{$\begin{array}{l}\text { 1- The causes } \\
\text { of opposition } \\
\text { (or conflict) }\end{array}$} & \multirow{16}{*}{$\begin{array}{l}0.748 \\
>0.5 \\
\text { The variables } \\
\text { are } \\
\text { interrelated }\end{array}$} & \multirow{16}{*}{$\begin{array}{l}0.000<0.5 \\
\text { The variables } \\
\text { are correlated. }\end{array}$} & \multirow{16}{*}{$\begin{array}{l}0.778> \\
0.60 \\
\text { This means } \\
\text { that } 77.8 \% \text { of } \\
\text { the scores are } \\
\text { true, so the } \\
\text { variables are } \\
\text { well } \\
\text { interrelated }\end{array}$} & $37.619 ; 14.415 ; 13.651$ & \multirow{16}{*}{$\begin{array}{l}0.000<0.05 \\
\text { significant }\end{array}$} & \multirow{4}{*}{$\begin{array}{l}\text {-Young are } \\
\text { holders of } \\
\text { diplomas that are } \\
\text { superior to those } \\
\text { of the older; } \\
\text { Sig }=0.018<0.05\end{array}$} \\
\hline & & & & The first dimension extracted & & \\
\hline & & & & $\begin{array}{l}\text { explains } 37.619 \% \text { of the } \\
\text { variance of the phenomenon. } \\
\text { The most correlated factors }(>\end{array}$ & & \\
\hline & & & & & & \\
\hline & & & & & & \multirow{3}{*}{$\begin{array}{l}\text {-Some older } \\
\text { workers accuse } \\
\text { young people of } \\
\text { incompetence at }\end{array}$} \\
\hline & & & & (1) There is a lack of collective & & \\
\hline & & & & between the older employees & & \\
\hline & & & & and the young of the company; & & \multirow{2}{*}{$\begin{array}{ll}\text { work; } & \text { Sig }= \\
0.000<0.05 & \end{array}$} \\
\hline & & & & (2) Young are holders of & & \\
\hline & & & & diplomas that are superior to & & \multirow{4}{*}{$\begin{array}{l}\text {-Young workers } \\
\text { accuse the older } \\
\text { of incompetence } \\
\text { at work. }\end{array}$} \\
\hline & & & & those of the older; & & \\
\hline & & & & (3) Some older workers accuse & & \\
\hline & & & & young people of incompetence & & \\
\hline & & & & at work; & & \multirow{3}{*}{$\begin{array}{l}\text { Sig }=0.000<0.05 \\
\text { significant }\end{array}$} \\
\hline & & & & (4) Young workers accuse the & & \\
\hline & & & & older of incompetence at work. & & \\
\hline
\end{tabular}




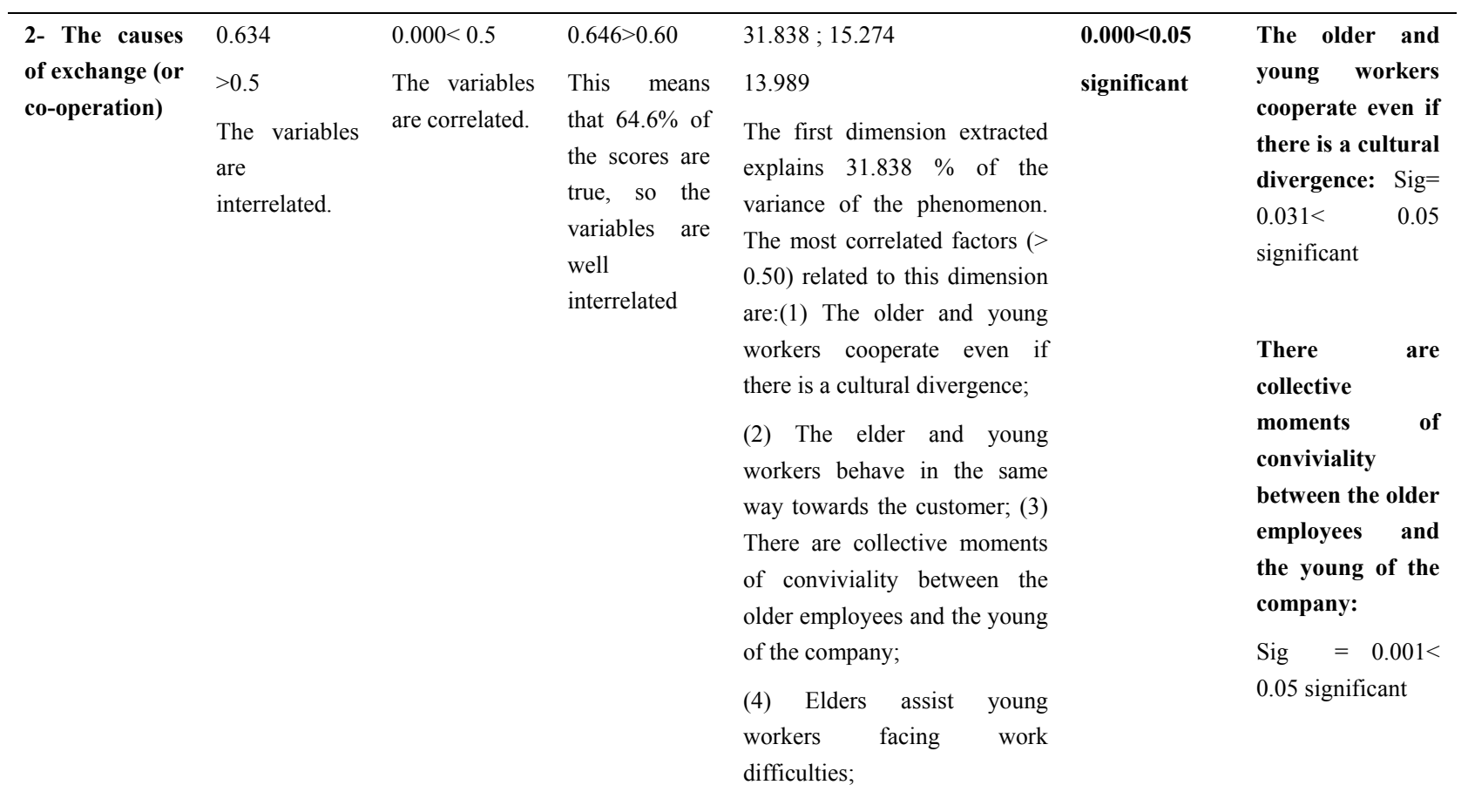

Source: Authors.

Given these results, it appears that the intergenerational cooperation at work may be absent in the engineering sector because the scale is not valid or reliable and the results reveal a single cause of opposition or conflict. On the other hand, the investigation allowed the detection of three causes of opposition or conflicts and two causes of exchanges or cooperation in the food industry sector.

\section{Discussion and Limitations}

Before discussing our results, we will present a more sophisticated modeling of the intergenerational relationship at work in Lebanon in the engineering and food industry sectors. 


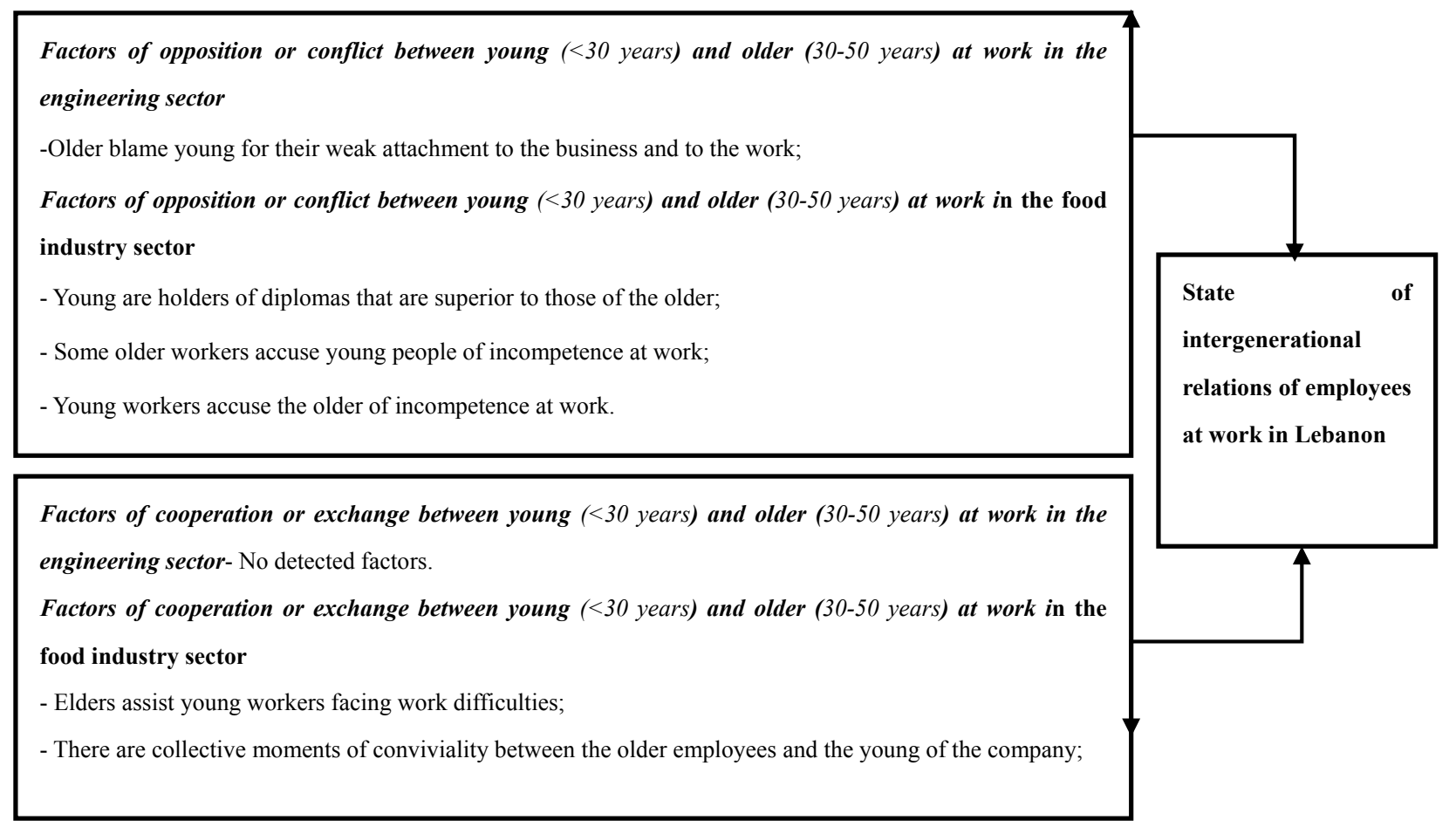

Figure 2. Towards a more sophisticated modeling of the intergenerational relationship at work in Lebanon in the engineering and the food industry sector

Source: Authors.

It seems important to note that our findings have highlighted the state of intergenerational relations at work in Lebanon for the first time, to our knowledge, even though the study is restricted to two sectors of activity. Our results will be discussed below in practical and theoretical terms.

At the practical level, we will present suggestions to the CEOs of companies to better manage problems between generations in the two sectors of activity of our study. In the engineering sector, older people blame young people for their lack of attachment to the business and to the work. This perceived weakness stems from the fact that older people do not agree very well with young people and instead see themselves as experts in the field of engineering. In this context, we suggest to the CEOs of the sector to encourage collective and friendly moments between the elders and the young people of their company. In the food industry, seniors accuse young people of incompetence at work and vice versa, which can deteriorate the social climate. We advise the CEOs of the activity to administer questionnaires to each group to their respective members to formalize the points of incompetence identified by the other group with the recommended solutions to mitigate or eliminate them. In this way, CEOs will be able to interpret the results obtained and, for example, ask older people to help young people facing work difficulties and/or offer training to the concerned groups. The accusations made will diminish over time, once the skills acquired by each and the collaboration between the two age groups established. Confidence will once again be established in those elders who seem to be more complex than young people holders of diplomas higher than their own. Similarly, co-apprenticeship between the elders and the young reinforces the confidence of the elders. Given that factors of cooperation or exchanges between young and older workers in the engineering sector have not been detected, it is difficult to conclude in any way with the available data in order that CEOs foster a climate of cooperation between engineers. However, perhaps an obligatory intergroup work would be necessary and could be attempted to improve these relationships. It should be noted that an improvement in these intergenerational relationships at work often has a positive impact on the performance of the company at all levels, particularly concerning the contacts especially with customers who will notice the good cooperation of various employees.

At the theoretical level, our work partially confirms the literature linked to a few factors causing intergenerational conflicts between employees. The intergenerational opposition factor that most confirms the literature in the context of the engineering sector in Lebanon is the fact that older people blame young people for their weak attachment to the business and to the work (already confirmed by Rosanvallon in 2013). The factors 
explaining intergenerational conflicts in the Lebanese food industry, which reinforce the findings in the literature, are as follows: Young are holders of diplomas that are superior to those of the older (already confirmed by Delay, 2008a, 2008b) and young people accuse the older of incompetence at work (seen by Delay, 2008 a). Our work partially questions the literature concerned by a single factor of intergenerational co-operation at work (co-apprenticeship young/old and overall training of young people by the older). Our research shows that, in the case of the food industry sector, elders assist young workers facing work difficulties and enjoy moments of conviviality with them, which is different from Rosanvallon's conclusions (2013) who noticed that older people do not help young people to solve the difficulties encountered during their work and that the two generations do not enjoy together moments of conviviality. We note that the work of Delay (2008) and Rosanvallon (2013) were conducted in France. It seems that the results of our work partially question the literature related to the factors of opposition or intergenerational cooperation at work due to a different cultural context.

Our conducted research is not without limits. As a result, we were not able to contact young employees on the one hand and older employees on the other (in other words those directly involved in the subject) who might have a different point of view than CEOs. These employees could present their views on the causes of conflicts and cooperation between generations at work. This lack of triangulation of data sources constitutes a gap to be filled during the continuation of the research.

The methodological limitations can be reduced to the crucial questions of the internal and external validity of our work. In many studies, internal validity is a priority and attention must be paid to obtaining reliable results before attempting the generalization (Royer and Zarlowski, 2007). We believe that our results are rather reliable given the sizes of our samples. In other words, we can believe in some internal validity of our study. Concerning the external validity, it seems partial because the study was carried out in only two regions (the city of Beirut and Mount of Lebanon), which is certainly not totally representative of the country and, consequently, the results highlighted are not generalizable to the whole geographical territory of Lebanon. A second remark is to be made concerning the questionnaire considered as very short and simple regarding the wording of its questions. Given that our research is mainly exploratory, a new questionnaire more comprehensive and more detailed addressed to the stakeholders of other sectors of activity localized throughout the Lebanese territory, would be useful to administer in order to better understand the problem of conflicts or cooperation between generations at work and to refine the model developed at the end of our investigation.

\section{Conclusion}

In this work, we have exclusively considered the point of views of CEOs on the causes of conflictual relations or cooperation between generations at work. Through administered questionnaires, we have identified the key findings above.

On a practical level, we suggest that companies recruit more young people because the percentage of unemployed young (from 20 to 29 years) is the highest with $42 \%$ in 2012 (figures from the Ministry of Labor 2014 cited by Ghosn, 2015 ) and 30\% in 2016 (Belga, 2016).

Our results reveal some factors of opposition or generational conflicts rather than factors of cooperation or exchange. We suggest that CEOs promote collective and friendly moments between the company's elder and young employees. It seems that this will improve the relations between them, promote exchange and resolve many types of conflict. This will also give a positive impression of the company's image for its stakeholders both internal and external and inevitably favor its performance at all levels.

At the theoretical level, the work results partially confirm the literature related to some factors causing intergenerational conflicts and partially call into question the only factor of intergenerational cooperation in the company. Our analysis seems to enrich the literature by highlighting certain factors that give rise to conflicts and intergenerational cooperation - see above - detected for the first time in Lebanon - to our knowledge - in the two sectors of activity chosen (Engineering and food industry).

Regarding the research prospects, the view of young and older employees on the subject treated and the comparisons that can be made with the results of the Lebanese CEO's views represent a promising track although difficult to follow because of confidentiality and the local context in management research. But it is a direction that should not be neglected if we want to better identify the factors of intergenerational conflict and cooperation in order to reduce the firsts and to develop the seconds to increase the performance of employees in companies.

In addition, we limited our study to two sectors, engineering, and food industry. Further research could be extended to all industrial, banking, agricultural and construction sectors in order to be able to make interesting comparisons on the subject and to draw lessons from it to improve the performance of the companies. 


\section{References}

Abrudan, M. M., Matei, M., \& Roman, T. (2016). The young generation of employees and their attitude towards work - a comparison of three countries. Current science, 111(6), 988-993.

Belga, (2016). Le taux de chômage des jeunes devrait croître en 2016. Retrieved from http://www.7sur7.be/7s7/fr/1502/Belgique/article/detail/2839028/2016/08/24/Le-taux-de-chomage-des-jeun es-devrait-croitre-en-2016.dhtml

CAS Report. (2009). Enquête sur le statut des enfants et des mères au Liban en 2009. Retrieved from http://www.cas.gov.lb/images/Mics3/MISC3_new/Labor\%20force\%20in\%202009.pdf

Chauvel, L. (1998). Le Destin des générations. Structures sociales et cohorts enFrance au XX siècle, Paris, PuF.

DELAY, B. (2008a). Les rapports entre jeunes et anciens dans les grandes entreprises. La responsabilité organisationnelle dans la construction de dynamiques intergénérationnelles coopératives. Document de travail, $\mathrm{n}^{\circ}$ 103, Centre d'études de l'emploi. Retrieved from file:///C:/Users/toshiba/Downloads/103-jeunes-entreprises-responsabilites-intergenerationnelle.pdf

DELAY, B. (2008b). Les jeunes : un rapport au travail singulier? Une tentative pour déconstruire le mythe de l'opposition entre les âges. Document de travail, $\mathrm{n}^{\circ} 104$, Centre d'études de l'emploi. Retrieved from file:///C:/Users/toshiba/Downloads/104-travail-singulier-opposition-age.pdf

Dubar, C. (2000). La Socialisation. Construction des identités sociales et professionnelles. Paris, Armand Colin.

Ghosn, N. (2015). Enquête sur le chômage des jeunes libanais. Retrieved from http://fr.annahar.com/article/280556-ce-que-lon-ignore-du-chômage-chez-les-jeunes-au-liban

Hughes, E. C. (1958). Men at their Work. Glenoce, The Free Press.

Krahn, H., \& Galambos, N. (2014). Work values and beliefs of 'Generation X' and 'Generation Y'. Journal of YouthStudies, 17(1), 92-112. DOI: 10.1080/13676261.2013.815701.

Longuenesse, E. (2011). Marché du travail et droits sociaux au Liban et au Proche-Orient. Retrieved from https://ifpo.hypotheses.org/1874

Méda, D., \& Vendramin, P. (2010). Les générations entretiennent-elles un rapport différent au travail? La revue sociologies. Retrieved from https://sociologies.revues.org/3349?lang=en\#quotation

MoAtTy, F. (2004). L'évolution du rôle du capital scolaire dans le modèle sociétal français d'accès à l'informatique au travail. "Massification" ou "démocratisation de l'accès"? Réseaux, 127(5-6), 83-114.

Paturel, R. (2004). Les choix méthodologiques de la recherche doctorale française en entrepreneuriat; Remise en cause partielle d'idées préconçues. Revue de l'Entrepreneuriat, 3(1), 47-65. Retrieved from https://doi.org/10.3917/entre.031.0047

Pialoux, M., Weber, F., \& Beaud, S. (1991). Crise du syndicalisme et dignité ouvrière. Politis, 14.

Rahmil, D. J. (2016). Young people at work: the myth of opposition between the generations. Retrieved from http://digital-society-forum.orange.com/en/les-forums/285-jeunes_au_travail_le_mythe_de_lopposition_e ntre_les_age

Rosanvallon, J. (2013). Les générations au travail : des cultures différentes ou un collectif qui se méconnait ? Le cas des techniciens d'EDF. La nouvelle revue du travail. Retrieved from https://doi.org/10.4000/nrt.987

ROYER, I., \& ZARLOWSKI, P. (2007). Le design de la recherche. In Thietart, R. A. (Ed.), Méthode de recherche en Management (p. 560).

Wagner, I. (2004). La formation des violonistes virtuoses : les réseaux de soutien. Sociétés contemporaines, 56, 133-163. https://doi.org/10.3917/soco.056.0133

World Bank Report. (2015).Taux de participation à la population active, femmes (\% de la population féminine âgée de 15 ans et plus) (estimation modélisée OIT). Retrieved from http://donnees.banquemondiale.org/indicateur/SL.TLF.CACT.FE.ZS 


\section{Copyrights}

Copyright for this article is retained by the author(s), with first publication rights granted to the journal.

This is an open-access article distributed under the terms and conditions of the Creative Commons Attribution license (http://creativecommons.org/licenses/by/4.0/). 